Arq. Bras. Med. Vet. Zootec., v.69, n.4, p.807-814, 2017

\title{
Propriedades mecânicas de dois padrões de sutura e dois tipos de fios aplicados às tenorrafias dos equinos
}

[Tenorrhaphy in horses: comparison of the mechanical properties of two different suture patterns and suture materials]

R.R. Corrêa ${ }^{1}$, C.A.M. Pereira ${ }^{2}$, N.C. Frias ${ }^{3}$, D.C. Baccarelli ${ }^{4}$, A.L.V. Zoppa ${ }^{5}$

\author{
${ }^{1}$ Faculdade de Medicina Veterinária e Zootecnia - Universidade de São Paulo - São Paulo, SP \\ ${ }^{2}$ Hospital das Clínicas - Faculdade de Medicina - Universidade de São Paulo - São Paulo, SP \\ ${ }^{3}$ Médica veterinária Residente - Hospital Veterinário - Faculdade de Medicina Veterinária e Zootecnia - \\ Universidade de São Paulo - São Paulo, SP \\ ${ }^{4}$ Aluna de pós-graduação - Faculdade de Medicina Veterinária e Zootecnia - Universidade de São Paulo, SP \\ ${ }^{5}$ Faculdade de Medicina Veterinária e Zootecnia - Universidade de São Paulo - São Paulo, SP
}

\begin{abstract}
RESUMO
As lesões traumáticas dos membros que resultam em secções tendíneas são problemas comuns na clínica equina. Diversas complicações têm sido associadas à reparação dos tendões nessa espécie. O objetivo do presente trabalho foi avaliar biomecanicamente dois padrões de sutura e dois diferentes materiais aplicados às tenorrafias. Vinte e quatro peças de tendão flexor digital profundo de equinos foram seccionadas e suturadas em padrão locking loop duplo (grupo 1, com polipropileno; grupo 2, com poliglactina) ou em padrão locking loop simples associado à sutura de epitendão (grupo 3, com polipropileno; grupo 4, com poliglactina). Os corpos de prova foram submetidos a ensaios mecânicos de tração, em que se determinaram valores de força mínima, força máxima e pico de força, além do afastamento observado entre os cotos durante o pico máximo de força. Para avaliação dos resultados, foram utilizados os métodos ANOVA e os não paramétricos de Kruskal-Wallis e Mann-Whitney $(\mathrm{P} \leq$ $0,05)$. Os maiores valores de força máxima foram documentados no grupo 3 . Os valores de força mínima foram maiores nos grupos 3 e 4 que nos grupos 1 e 2, mas não diferiram significativamente entre os grupos 3 e 4 . Os valores de pico de força foram maiores nos grupos 1 e 2 que no grupo 4, mas não diferiram significativamente no grupo 3. O afastamento foi maior nos grupos 1 e 2 quando comparados aos grupos 3 e 4 . O padrão locking loop simples, com sutura de epitendão, atingiu maior resistência quando avaliado afastamento de até 3 milímetros entre os cotos tendíneos, sendo considerado padrão de escolha para aplicação clínica, tendo em vista os resultados obtidos neste trabalho.
\end{abstract}

Palavras-chave: equino, tenorrafia, tendão, sutura

\begin{abstract}
Traumatic distal limb injuries resulting in tendon rupture are common in equine practice. Several complications have been associated with tendon repair in horses. The aim of this study was to compare the biomechanical properties of two tenorrhaphy techniques using two different suture materials. Twentyfour equine deep digital flexor tendon specimens were transected and sutured with the double locking loop pattern (polypropylene, group 1; polyglactin, group 2) or the single locking loop pattern with peripheral epitendon suture (polypropylene, group 3; polyglactin, group 4). Specimens were submitted to mechanical strain testing. Maximum, minimum and peak strain, and maximum, minimum and peak gap formation were evaluated. ANOVA and the non-parametric Kruskal-Wallis and Mann-Whitney tests were used $(P \leq 0.05)$. Higher maximum strength values were documented in group 3 . Minimum strength values were higher in groups 3 and 4 than 1 and 2, but did not differ significantly between groups 3 and 4. Peak strength values were higher in groups 1 and 2 than 4, but did not differ significantly from group 3. Gap
\end{abstract}

Recebido em 13 de abril de 2015

Aceito em 4 de março de 2016

E-mail: romero@usp.br 


\section{Corrêa et al.}

formation was greater in groups 1 and 2 than 3 and 4. The single locking loop pattern with epitendon suture performed with polypropylene had greater resilience, yielded lesser gap formation (3 $\mathrm{mm})$ and is the pattern of choice for clinical application based on the results of this study.

Keywords: equine, tenorrhaphy, tendon, suture

\section{INTRODUCTION}

Tendon lacerations can vary from mild, with minimal signs of discomfort, to severe, with intense pain (Davis and Smith, 2006). Ruptured flexor tendons require immediate surgical intervention with apposition of the tendon edges for adequate healing (Moraes et al., 2002; Moraes et al., 2003; Jenson et al., 2005). Several complications have been described, including suture dehiscence, necrosis of the tendon edges or severe infection (Hataka et al., 2000, Moraes et al., 2002; Crowson et al., 2004).

Most surgeons familiar with tenorrhaphy procedures in horses report technical difficulties related to the choice of suture material and pattern (Reiners et al., 2002; Moraes et al., 2003; Zhao et al., 2004).

The aim of this study was to compare two different suture patterns and suture materials employed for tenorrhaphy of the equine deep digital flexor tendon and to evaluate the applicability of the techniques studied in equine practice. We also wanted to determine which of the combinations of suture pattern and material routinely employed by Brazilian surgeons is the most resistant and capable of minimizing gap formation between ruptured tendon edges.

\section{MATERIAL AND METHODS}

Based on literature data and a previous survey among Brazilian surgeons working in different states, the double locking loop suture pattern and the single locking loop pattern with epitendon suture (the latter based on the report by Moraes et al.; 2002) were selected as the variables to be tested in this study. Size 2 braided multifilament polyglactin 910 and polypropylene monofilament suture materials were also selected for testing.

Twenty-four equine cadaver forelimbs collected from adult horses with no history of flexor tendon injuries, weighing between 400 and $500 \mathrm{~kg}$, dead or euthanized due to causes unrelated to the locomotor system were used in this study. Immediately after death or euthanasia the deep digital flexor tendon was dissected, wrapped in surgical pads soaked with lactated Ringer's solution, placed in identified plastic bags and stored deep-frozen for future use.

The tendon specimens were allocated to four groups of six tendons each. Following thawing for 12 hours at room temperature, the midpoint of the metacarpal length of the deep digital flexor tendon was identified and transected with a scalpel blade. Tenorrhaphy was performed either with the double locking loop pattern (polypropylene, group 1; polyglactin, group 2) or the single locking loop pattern with peripheral epitendon suture (polypropylene, group 3; polyglactin, group 4). In the double locking loop groups, the first and second sutures were placed $20 \mathrm{~mm}$ and $10 \mathrm{~mm}$ away from the transection line. In the single locking loop groups, the locking loop suture was placed $15 \mathrm{~mm}$ away from the transection line. Given the need to assess the gap formed between the tendon edges, all knots were placed palmarly. The epitendon was sutured with four simple interrupted stiches placed $5 \mathrm{~mm}$ away from the transection line, one the medial, one on the lateral and two on the palmar aspect of the tendon.

The test specimen consisted of the sutured tendon and had a total length of $150 \mathrm{~mm}$. The tension test was performed using a universal mechanical testing machine with a load cell of $100 \mathrm{kgf}$ adjusted for a $50 \mathrm{kgf}$ scale. Displacement resolution was $0.01 \mathrm{~mm}$ and testing speed was $10 \mathrm{~mm} / \mathrm{min}$. Mechanical testing data were sampled using a computer program with a 12 bit resolution system allowing for the documentation of force and displacement parameters. Data acquisition rate was 30 samples per second.

A video-controlled extensometry system was developed to measure the gap formed between the tendon edges and relate it to the tension exerted on the test specimen. Frontal and lateral views were obtained with the aid of a mirror. Three equidistant circles $15 \mathrm{~mm}$ apart were 
marked in each plane (frontal and lateral). These frontal and lateral planes of a template were then aligned with the corresponding planes on the tendon, with the inferior markers at the same level as the apposed tendon edges (Figure 1).

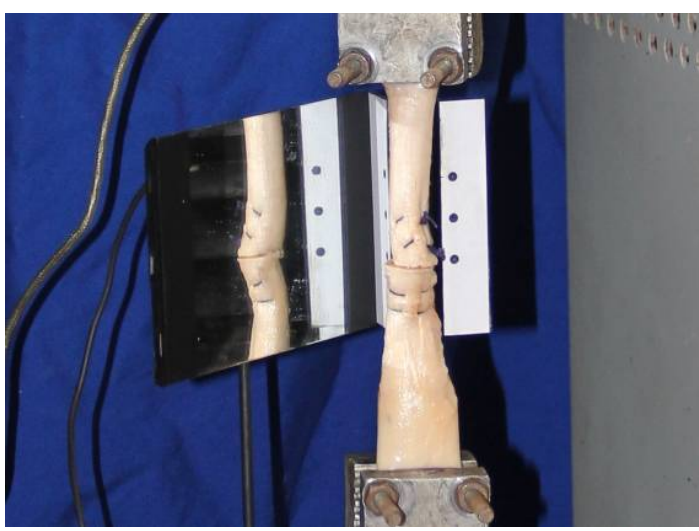

Figure 1. Template positioned next to the anastomosed tendon. The frontal and lateral aspects of the test specimen can be seen reflected on the mirror (left).

Calibration was required to assess the gap formed between the tendon edges. To achieve calibration, the actual distance in $\mathrm{mm}$ between the center of the inferior and superior markings on the template was related to the distance in pixels between the same points. A mean relationship of $0.1 \mathrm{~mm} /$ pixel was determined.

Upper and lower limits were determined based on 2 horizontal lines drawn immediately above and below the tendon edges, that were adjusted for "initial" as well as "final" frames (Figure 2 and 3).

The analysis was performed between the time points corresponding to the initial and final frames, at $0.25 \mathrm{~s}$ intervals. In each of the frames analyzed, the gap formed between the tendon edges was determined for each tracking line.

The strength magnitudes corresponding to the same time points recorded were identified using the computer program. The final analysis was performed in such a way that the program could find the maximum and minimum strength values corresponding to a $3 \mathrm{~mm}$ gap in all trackings, as well as minimum, maximum and mean gaps formed during the trial.

Tenorrhaphy failure was defined as the point where a $3 \mathrm{~mm}$ gap was formed between the tendon edges. This parameter was selected as a reference for failure assuming that primary healing would be impaired when ruptured tendon edges are more than $3 \mathrm{~mm}$ apart.

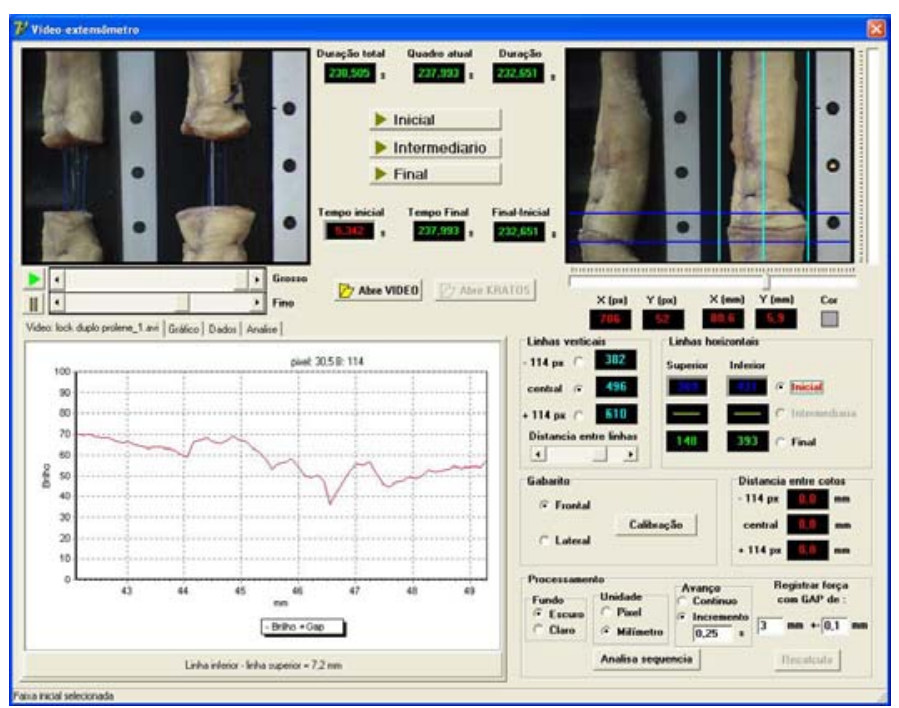

Figure 2. Video extensometry software: selection of the first frame (LED on; start of the trial). The graph on the left displays the vertical tracking (middle vertical line) of the reflection on the image between the upper and lower limits (horizontal lines). 


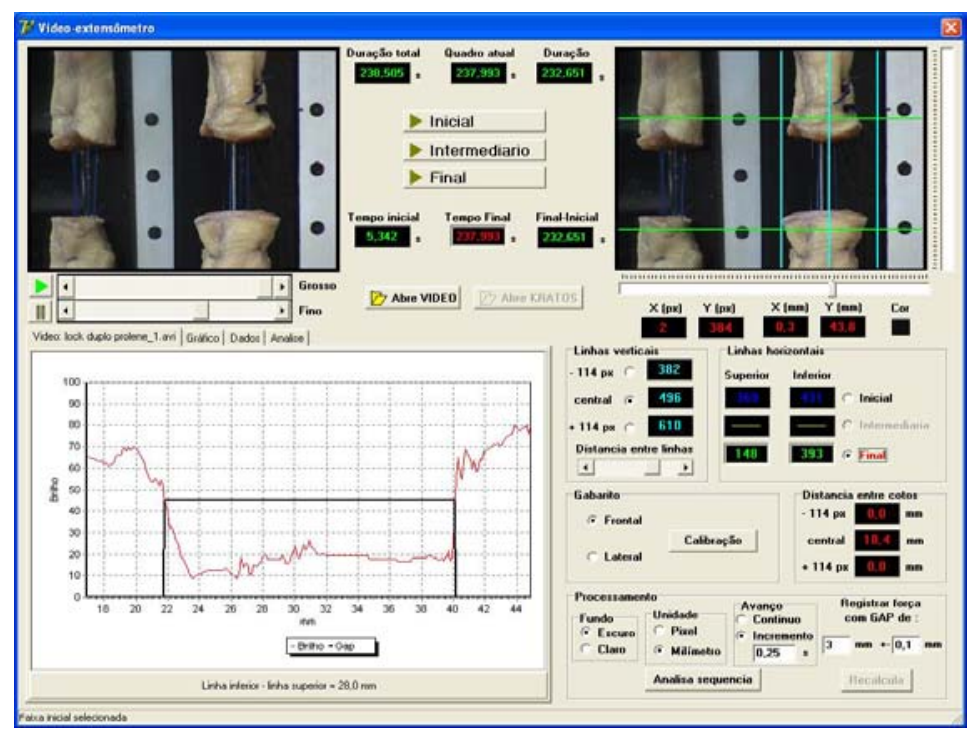

Figure 3. Video extensometry software: selection of the last frame (LED off; end of the trial). The graph on the left displays the vertical tracking (middle vertical line) of the reflection on the image between the upper and lower limits (horizontal lines).

"Minimum strength" was defined as the tension required to induce gap formation and "maximal strength" as the tension required to create a $3 \mathrm{~mm}$ gap. "Peak strength" was defined as the maximum tension exerted on the tenorrhaphy line prior to suture failure. Failure was defined as the point from which tension dropped abruptly due to suture material or tendon tissue breakdown.

\section{RESULTS}

The analysis of variance (ANOVA) and the multiple comparison correction of Bonferroni were employed to compare the results documented in the 4 groups (Table 1) in this study. Where the ANOVA assumptions were not fulfilled, the non-parametric Kruskal-Wallis and Mann-Whitney tests were used. The level of significance was set at $5 \%(\mathrm{P} \leq 0.05)$.

All variables (maximum, minimum and mean strength and maximum, minimum and mean gap) differed significantly between groups.

Maximum strength differed significantly between all groups, except groups 1 and 2 . Minimum strength differed significantly between groups 1 and 3, 2 and 3, and 2 and 4. Peak strength differed significantly between groups 1 and 4 and 2 and 4 . Minimum, maximum and mean gap under peak strength differed significantly between groups 1 and 3, 1 and 4, 2 and 3 and 2 and 4 (Table 1).

The confidence intervals for maximum, minimum and peak strength and for maximum, minimum and mean gap between tendon edges are displayed on Figures 4, 5, 6, 7, 8 and 9.

\section{DISCUSSION}

The choice of suture material for tendon repair is debatable. However, some studies recommend the use of large-sized non-absorbable monofilament material (Moraes et al., 2002; Davis and Smith, 2006; McIlwraith, 2006). Techniques where the sutures are placed between the collagen fibrils of the tendon and those involving the epitendon provide a more robust repair than those that are predominantly parallel to the collagen fibrils (Urbaniak et al., 1985). There are currently no guidelines available for the choice of suture material for tendon repair in horses, given that previous studies have led to variable results and failed to come up with definitive answers. The inclusion of tendon fibrils in the suture is a valid technique, although the number of sutures and the size of the suture material may reduce the resistance of the sutured edges, increasing tendon frailty. Also, the excessive amount of suture material going through the tendon may impair local blood flow, leading to tendon ischemia and necrosis, and ultimately suture breakdown. 
The locking loop suture pattern interferes minimally with the tendon structure, has strong holding capacity and leaves little suture material exposed (Turner, 1984). A study comparing the locking loop with epitendon suture, the modified Becker and the double loop patterns concluded that the locking loop yields superior results
(Moraes et al., 2002). Contrasting with previous works in monkeys (Greenwald et al., 1994; Greenwald et al., 1995), a research group reported that the locking loop pattern with epitendon suture is strong enough to prevent gap formation between ruptured tendon edges in horses (Moraes et al., 2002; Moraes et al., 2003).

Table 1. Descriptive analysis of the variables studied: maximum, minimum and peak strength values and maximum, minimum and mean gap per group

\begin{tabular}{|c|c|c|c|c|c|c|}
\hline Specimens & Group 1 & Group 2 & Group 3 & Group 4 & Total & p-value \\
\hline \multicolumn{7}{|l|}{ Maximum strength } \\
\hline Mean (SD) & $78(42.4) \mathrm{a}$ & 115.1(13.3)a & $233.5(23.7) b$ & $174.3(33.7) \mathrm{c}$ & $150.2(66.6)$ & $<0.001 *$ \\
\hline Median & 79 & 115.3 & 232.2 & 165 & 136.3 & \\
\hline (Min; Max) & $(24.3 ; 124.5)$ & $(97.8 ; 138.2)$ & $(207.6 ; 267.4)$ & $(134.3 ; 230.4)$ & $(24.3 ; 267.4)$ & \\
\hline Total of specimens & 6 & 6 & 6 & 6 & 24 & \\
\hline \multicolumn{7}{|l|}{ Minimum strength } \\
\hline Mean (SD) & 46.2(36.8)ac & $62(29) a$ & $150.1(24) b$ & $117.2(45.8) b c$ & $93.8(53.7)$ & $<0.001 *$ \\
\hline Median & 50.1 & 62.3 & 157.7 & 132.2 & 95.8 & \\
\hline (Min; Max) & $(7 ; 106.5)$ & $(27.4 ; 102.6)$ & $(111 ; 176.1)$ & $(40.4 ; 169.9)$ & $(7 ; 176.1)$ & \\
\hline Total of specimens & 6 & 6 & 6 & 6 & 24 & \\
\hline \multicolumn{7}{|l|}{ Peak strength } \\
\hline Mean (SD) & $287.7(40.5) \mathrm{a}$ & 279.1(30.6)a & 237(21.5)a.b & $194.8(41.8) b$ & 249.7(49.7) & $0.001 *$ \\
\hline Median & 286.2 & 272.3 & 232.4 & 170.2 & 254 & \\
\hline (Min; Max) & $(224.2 ; 331.8)$ & $(246.8 ; 327)$ & $(212.7 ; 270.8)$ & $(163.6 ; 254.9)$ & $(163.6 ; 331.8)$ & \\
\hline Total of specimens & 6 & 6 & 6 & 6 & 24 & \\
\hline \multicolumn{7}{|l|}{ Minimum gap } \\
\hline Mean (SD) & 21.3(5.9)a & $16.1(2.8) \mathrm{a}$ & $2.8(1.7) \mathrm{b}$ & $2.9(0.9) \mathrm{b}$ & $10.8(8.9)$ & $<0.001 *$ \\
\hline Median & 20.6 & 16.4 & 2.4 & & 9.3 & \\
\hline (Min; Max) & $(16.1 ; 32.4)$ & $(12.5 ; 20)$ & $(1.4 ; 6.1)$ & $(1.5 ; 4.1)$ & $(1.4 ; 32.4)$ & \\
\hline Total of specimens & 6 & 6 & 6 & 6 & 24 & \\
\hline \multicolumn{7}{|l|}{ Maximum gap } \\
\hline Mean (SD) & 23.7(4.2)a & 19.7(3.3)a & $5.8(0.7) \mathrm{b}$ & $5.8(1.5) b$ & $13.8(8.7)$ & $<0.001 *$ \\
\hline Median & 22.7 & 20.9 & 5.7 & 6.1 & 10.7 & \\
\hline (Min; Max) & $(20.5 ; 32.1)$ & $(14 ; 23.1)$ & $(5.1 ; 7)$ & $(4 ; 7.4)$ & $(4 ; 32.1)$ & \\
\hline Total of specimens & 6 & 6 & 6 & 6 & 24 & \\
\hline \multicolumn{7}{|l|}{ Mean gap } \\
\hline Mean (SD) & $22.5(5) \mathrm{a}$ & $17.9(2.8) \mathrm{a}$ & $4.3(1.1) \mathrm{b}$ & $4.4(1.1) b$ & $12.3(8.7)$ & $<0.001 *$ \\
\hline Median & 21.7 & 18.3 & 4 & 4.7 & 9.9 & \\
\hline (Min; Max) & $(18.5 ; 32.3)$ & $(13.3 ; 21.6)$ & $(3.4 ; 6.6)$ & $(2.8 ; 5.8)$ & $(2.8 ; 32.3)$ & \\
\hline Total of specimens & 6 & 6 & 6 & 6 & 24 & \\
\hline
\end{tabular}

* Within each line, values with different lowercase superscript letters are significantly different.

** p-value according to ANOVA.

*** p-value according to the Kruskal-Wallis non-parametric test. 


\section{Corrêa et al.}

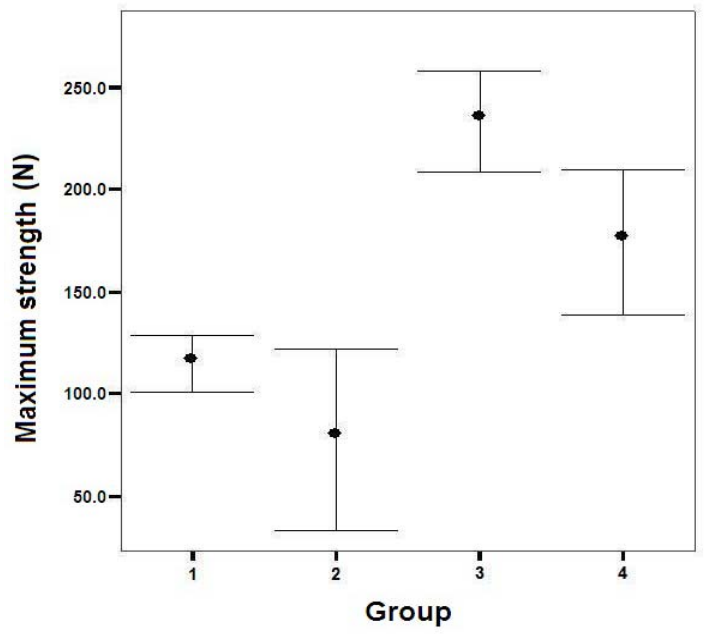

Figure 4. 95\% confidence interval for maximum strength values in groups 1, 2, 3 and 4.

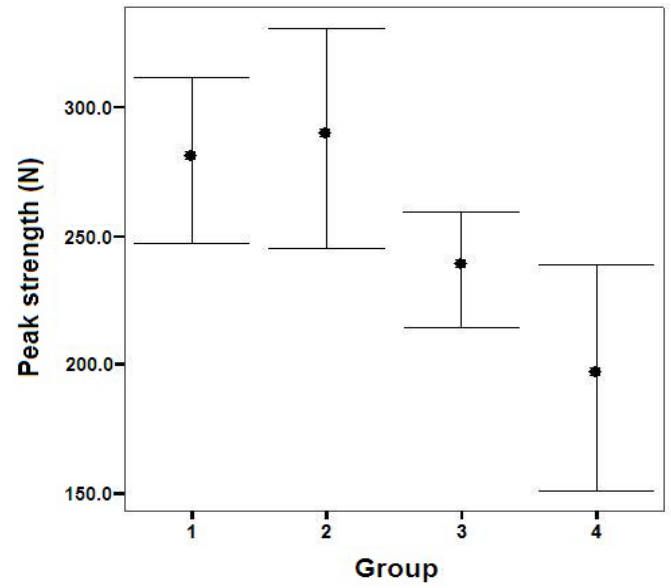

Figure $6.95 \%$ confidence interval for peak strength values in groups 1, 2, 3 and 4 .

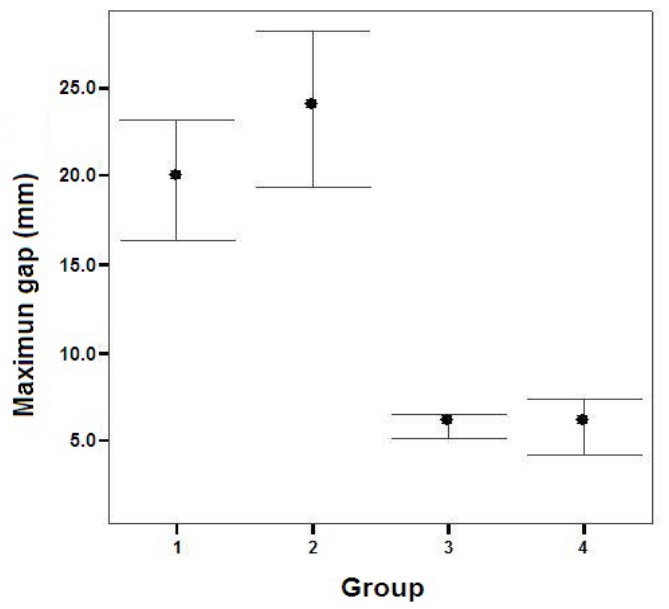

Figure $8.95 \%$ confidence interval for maximum gap under peak strength in groups 1, 2, 3 and 4.

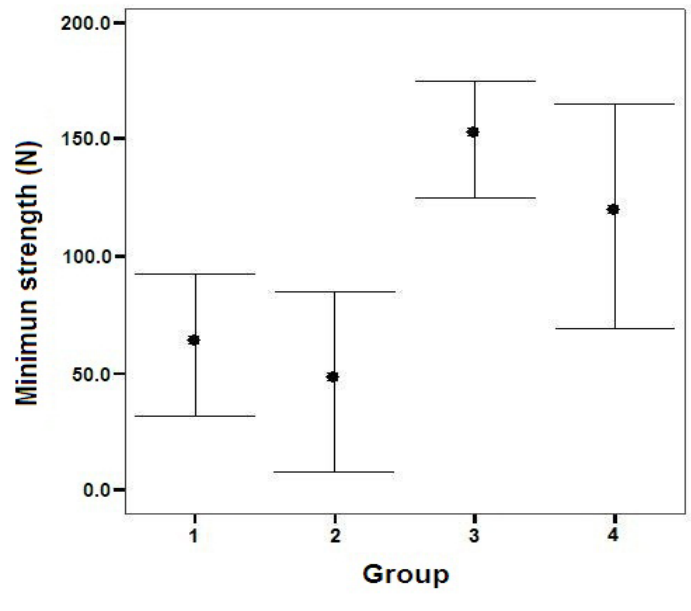

Figure 5. 95\% confidence interval for minimum strength values in groups 1, 2, 3 and 4 .

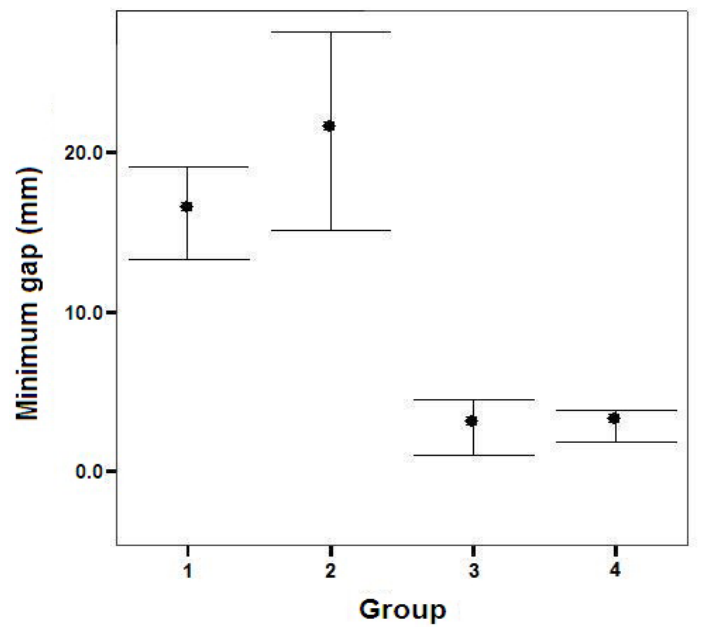

Figure 7. 95\% confidence interval for minimum gap under peak strength in groups 1, 2, 3 and 4.

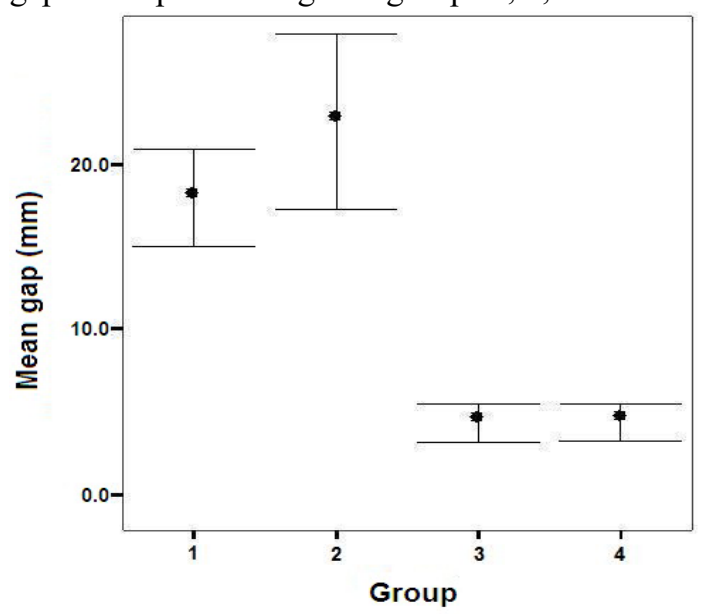

Figure 9. 95\% confidence interval for mean gap under peak strength in groups 1, 2, 3 and 4 . 
In this study, the double and the single locking loop patterns allowed for excessive gap formation between the tendon edges. The smallest gap was achieved with the locking loop pattern with epitendon suture, possibly due to the influence of the epitendon suture. Therefore, investigation of the inclusion of the epitendon in other suture patterns reported to be less efficient due to gap formation is warranted. Also, according to previously published data (Manchio et al., 2009), the number of threads crossing the ruptured tendon edges may be more important than the suture pattern for the success of tenorrhaphy.

In this study, maximum strength differed significantly between all groups, with the exception of groups 1 and 2 (double locking loop suture), where suture material had no impact on suture resilience. Strength values were highest when the single locking loop with epitendon suture was employed (groups 3 and 4). However, a significant difference was observed between groups and better tensile strength indices were obtained with polypropylene. These results suggest that the single locking loop pattern with epitendon suture has greater clinical applicability and that, based on maximum strength alone, polypropylene is the suture material of choice. Based on the low maximum strength indices documented in this study, the double locking loop suture pattern cannot be advised for deep digital flexor tenorrhaphy in horses. The lack of significant differences between the different suture materials employed may indicate that suture failure occurred before the suture materials could be sufficiently put to test.

For the epitendon suture, four threads were passed through the palmar aspect of the tendon, 5 $\mathrm{mm}$ away from the transection line. This procedure was selected based on the surgical approach employed in most tenorrhaphy cases in horses, where only the palmar aspect of the tendon is exposed. Based on the results of this study, it could be argued that a larger number of threads, the inclusion of the dorsal aspect of the tendon or even the placement of the sutures at a greater distance from the transection line may further increase suture resilience.

The tension generated by a muscle on the respective tendon during weight bearing at rest or in motion has not been determined in horses. The actual tension applied on tenorrhaphy sites may thus be largely underestimated in ex vivo studies.

Minimum strength magnitudes differed significantly between groups 1 and 3 . Given the same suture material was employed in both groups (polypropylene) it can be argued that the single locking loop with epitendon suture is preferable over the double locking loop pattern. Significant differences were also observed between groups 2 and 3 and 2 and 4, again favoring the inclusion of the epitendon suture (Moraes et al., 2002).

Different suture materials did not impact the performance of the single locking loop pattern, suggesting that the choice of suture pattern may be more important than the choice of suture material in this case.

When peak strength was considered, the double locking loop pattern with either polypropylene or polyglactin was superior to the single locking loop pattern with polyglactin. However, when the double locking loop pattern with either suture material was compared with the single locking loop pattern using polypropylene (groups 1, 2 and 3) there were no significant differences between groups, despite higher strength indices in groups 1 and 2 (double locking loop).

Based on suture peak strength, tendon plates $(1500 \mathrm{~N})$ provide the most robust experimental method for tendon repair, followed by the triple loop $(313 \mathrm{~N})$ and double loop $(155 \mathrm{~N})$ suture patterns (Smith et al., 2011). Mean peak strength values documented in this study $(287.7 \mathrm{~N}$ for the double locking loop suture with polypropylene and $237 \mathrm{~N}$ for the single locking loop pattern with epitendon suture using polyglactin, respectively) are in agreement with reported maximum values (Smith et al., 2011).

Minimum, maximum and mean gap formed under peak strength were significantly larger in groups 1 and 2 than in groups 3 and 4. Hence, despite higher peak strength values, the double locking loop suture pattern tends to allow for more gap formation between the apposed tendon edges and is less indicated for use in clinical settings. 


\section{CONCLUSIONS}

Despite good peak strength indices, the double locking loop suture fails to prevent gapping between apposed tendon edges under maximum load. The single locking loop pattern with epitendon suture is more resistant to tension when performed with polypropylene than polyglactin. This suture pattern had the greatest resilience and yielded lesser gap formation (3 $\mathrm{mm}$ ) amongst all suture patterns studied and is the pattern of choice for clinical application based on the results of this study.

\section{REFERENCES}

CROWSON, C.L.; JANN H.W.; STEIN L.E. et al. Quantitative effect of tenorrhaphy on intrinsic vasculature of the equine superficial digital flexor tendon. Am. J. Vet. Res., v.65, p.279-282, 2004.

DAVIS, C.S.; SMITH, R.K.W. Diagnosis and management of tendon and ligament disorders. In: AUER, A.J.; STICK, A.J. Equine surgery. Philadelphia: Saunders Elsevier, 2006. p.10861111.

GREENWALD, D.P.; HONG, H.Z.; MAY JR, J.W. Mechanical analysis of tendon suture techniques. J. Hand Surg., v.19, p.641-647, 1994.

GREENWALD, D.P.; RANDOLPH, M.A.; HONG, H. et al. Augmented becker versus modified kessler tenorrhaphy in monkeys: dynamic mechanical analysis. J. Hand Surg., v.20, p.267-272, 1995.

HATAKA, A.; MORAES, J.R.E.; PAURA, D. et al. Efeito da localização do nó de sutura na recuperação morfofuncional do tendão flexor digital profundo do membro torácico do cão após tenorrafia experimental (effect of different suture knot placements on functional recover of the flexor digitorum profundus tendon (FDPT) of the toracic member of the dog after experimental tenorrhaphy). Braz. J. Vet. Res. Anim. Sci., v.37, p.56-64, 2000.

JENSON, P.W.; LILLICH, J.D.; ROUSH, J.K. et al. Ex vivo strength comparison of bioabsorbable tendon plates and bioabsorbable suture in a 3loop pulley pattern for repair of transected flexor tendons from horse cadavers. Vet. Surg., v.34, p.565-570, 2005.
MANCHIO, J.V.; SHASHIKANT, M.P.; SHRIVASTAVA, A. et al. Evaluation of a new 4-strand flexor tendon repair in a cadaveric porcine model. J. Hand Surg., v.34, p.102-107, 2009.

MCILWRAITH, W.C. Doenças das articulações, tendões, ligamentos e estruturas relacionadas (diseases of joints, tendons, ligaments and related structures). In: STASHAK, T.S. Claudicação em equinos segundo Adams: Adams lameness in horses. São Paulo: Roca, 2006. p.417-601.

MORAES, J.R.E.; FERRARO, G.C.; SHIMANO, A.C. et al. Propriedades mecânicas de três padrões de sutura no reparo de tendão do músculo flexor profundo do dedo em eqüinos (mechanical properties of three patterns of suture in the repair of tendon of the muscle deep digital flexor equine). Braz. J. Vet. Res. Anim. Sci., v.39, p.97-102, 2002.

MORAES, J.R.E.; FERRARO, G.C.; SHIMANO, A.C. et al. Propriedades mecânicas de três fios de sutura no reparo de tendão do músculo flexor profundo do dedo de cães (mechanical properties of three threads of suture in the repair of the tendon of the muscle deep digital flexor of dogs). Braz. J. Vet. Res. Anim. Sci., v.40, p.443-451, 2003.

REINERS, S.R.; JANN, H.W.; STEIN, L.E. et al. An evaluation of two autologous tendon grafting techniques in ponies. Vet. Surg., v.31, p.155-166, 2002.

SMITH, R.L.; MURPHY, D.J.; DAY, R.E. et al. An ex vivo biomechanical study comparing strength characteristics of a new technique with the three-loop pulley for equine tenorrhaphy. Vet. Surg., v.40, p.768-773, 2011.

TURNER, A.S. Large animal orthopedics. In: JENINGS, P.B. The practice of large animal surgery. Philadelphia: Saunders, 1984. p.918921.

URBANIAK, J.; CAHILL, J.D.; MORTENSON, R.A. Tendon methods: analysis of tensile strengths. Symposium on tendon surgery in the hand. Saint Louis: Mosby, 1985. p.70-80.

ZHAO, C.; AMADIO, P.C.; TANAKA, T. et al. Effect of gap size on gliding resistance after flexor tendon repair. J. Bone Jt. Surg., v.86, p.2482-2488, 2004. 